\title{
Incomplete sex chromosome pairing in oligospermic male hybrids of Mus musculus and $M$. musculus molossinus in relation to the source of the $Y$ chromosome and the presence or absence of a reciprocal translocation
}

\author{
P. de Boer and J. H. Nijhoff \\ Department of Genetics of the Agricultural University, Gen. Foulkesweg 53, \\ 6703 BM Wageningen, The Netherlands
}

Summary. A series of backcrosses of $\mathrm{T} 70 \mathrm{H} /+\mathrm{F}_{1}$ Mus musculus $\times$ Mus m. molossinus females $\times \mathrm{T} 70 \mathrm{H} / \mathrm{T} 70 \mathrm{H}$ Mus musculus males and of $\mathrm{a}+/+\mathrm{F}_{1}$ Mus musculus $\times$ M. m. molossinus male $\times \mathrm{T} 70 \mathrm{H} / \mathrm{T} 70 \mathrm{H}$ and $+/+$ Mus musculus females were set up to produce $\mathrm{T} 70 \mathrm{H} /+\mathrm{B}_{1}$ males with a Y chromosome of the 'musculus' (Y) or 'molossinus' $\left(\mathrm{Y}^{*}\right)$ type, and males with $\mathrm{T} 70 \mathrm{H} / \mathrm{T} 70 \mathrm{H} \mathrm{Y}$ and $+/+\mathrm{Y}^{*}$ karyotypes. Observations of late diplotene-metaphase 1 meiosis were carried out, besides estimates of the number of spermatozoa in the caput epididymidis and the frequency of abnormal sperm mophology. From two $\mathrm{T} 7 \mathrm{OH} /+\mathrm{F}_{1}$ sterile males, 114 pachytene spermatocytes were scored through the electron microscope after whole mount spreading on copper grids. It was concluded that: (1) the $\mathrm{T} 70 \mathrm{H} /+\mathrm{F}_{1}$ and $\mathrm{B}_{1}$ mice showed higher chiasma frequencies than did $\mathrm{T} 70 \mathrm{H} /+$ mice on a random-bred Swiss genetic background; (2) despite this effect, X,Y univalence frequently occurred in all karyotypes and there was a significant correlation $(0.81)$ between the sperm count and the fraction of primary spermatocytes with $\mathrm{X}, \mathrm{Y}$ univalents; (3) within the $\mathrm{T} 70 \mathrm{H} /+\mathrm{F}_{1}$ males, the sex chromosomes were unpaired in $36.8 \%$ of the pachytene spermatocytes scored, and when paired, the pairing segment was generally half the value of that for control spermatocytes; (4) the frequency of $\mathrm{X}, \mathrm{Y}$ univalence was influenced by the source of the $\mathrm{Y}$ chromosome but not by the presence of translocation heterozygosity. Within the $\mathrm{B}_{1}$ karyotypes, autosomal genetic factors must also be important for regulating pairing behaviour; (5) the presence of a reciprocal translocation, independent of $\mathrm{X}, \mathrm{Y}$ chromosome pairing, also affected the reduced sperm production in the hybrids; (6) spermatozoa of abnormal morphology were frequently produced, especially in the $B_{1}$ groups with translocation heterozygosity or homozygosity. The deviant shapes were associated with these factors and with the hybrid genetic background but not directly with the numbers of spermatozoa produced.

From these results and others in the literature it appears that insufficient $X, Y$ pairing can lead to sterility in male mice. Such insufficiency then acts as a cell lethal in primary spermatocytes, leading to degeneration mainly during the diplotenemetaphase 1 stages of the first meiotic division, thus preventing the development of secondary spermatocytes. 


\section{Introduction}

Hybrids between the house mouse (Mus musculus) and the subspecies Mus musculus molossinus (the Japanese house mouse) are reported to be fertile (Gray, 1953). An example of this fertility when the C57BL inbred strain is used is given by Bruce, Furrer, Goldberg \& Meistrich (1973). However, when we crossed T70H/T70H random-bred Swiss females with $M$. $m$. molossinus males, almost all descending male translocation heterozygotes were completely sterile whereas female $\mathrm{T} /+$ offspring showed a fertility pattern typical of translocation heterozygotes (Nijhoff, van Beek \& de Boer, 1977).

However, reciprocal translocations leading to azoo- or oligospermy against one genetic background but with fertility for another are known (Forejt, 1976). Besides major meiotic arrest between the primary spermatocyte and secondary spermatocyte stages, the sterile $T 70 \mathrm{H} /+\mathrm{F}_{1}$ males exhibited a very high level of sex chromosome univalence during diakinesis-metaphase 1 (Nijhoff et al., 1977). This factor has previously been observed in male sterile animals and probands (see Beechey, 1973). The present investigation was undertaken to (1) unravel the role of translocation heterozygosity in causing the hybrid sterility concerned and (2) separate its possible sterility-inducing component from that of the $\mathrm{X}, \mathrm{Y}$ separation observed. The pachytene pairing of the sex chromosomes in the sterile male mice is described and special attention is given to the origin of the $\mathrm{Y}$ chromosome and its effect on pairing.

\section{Materials and Methods}

Animals. The Japanese house mouse (Mus musculus molossinus) males were a gift from Professor A. Gropp, Lübeck. The karyotype of these animals, with special reference to the heterochromatin polymorphisms which distinguish this subspecies from the laboratory mouse, is given by Dev et al. (1975). The T70H/T70H homozygotes were from a random-bred Swiss $\mathrm{Cpb}(\mathrm{SE})$ background as were the karyologically normal animals used. More information concerning the $\mathrm{T}(1 ; 13) 70 \mathrm{H}$ translocation is given by Searle, Ford \& Beechey (1971) and de Boer (1976).

Crosses and observations. The initial cross, $M$. musculus $\mathrm{T} 70 \mathrm{H} / \mathrm{T} 70 \mathrm{H} q \times M . m$. molossinus $\delta$, yielded 14 fertile $\mathrm{T} 70 \mathrm{H} /+$ females (litter size $3.00 \pm 1.64, n=51$ ) and $18 \mathrm{~T} 70 \mathrm{H} /+$ males, of which only 2 proved fertile with normal females. One cross of a $M$. musculus $\mathrm{T} 70 \mathrm{H} /+q \times M$. m. molossinus $\delta^{\top}$ gave rise to 2 fertile $+/+$ male offspring.

One of these fertile males was backcrossed to $+/+$ and $\mathrm{T} 70 \mathrm{H} / \mathrm{T} 70 \mathrm{H}$ random-bred Swiss females and yielded $+/+\mathrm{B}_{1}$ and $\mathrm{T} 70 \mathrm{H} /+\mathrm{B}_{1}$ sons with the 'molossinus' $\mathrm{Y}$ chromosome (designated $\mathrm{Y}^{*}$ throughout this text). The fertile $\mathrm{T} 70 \mathrm{H} /+\mathrm{F}_{1}$ females were backcrossed to $\mathrm{T} 70 \mathrm{H} / \mathrm{T} 70 \mathrm{H}$ males and produced $\mathrm{T} 70 \mathrm{H} /+\mathrm{B}_{1}$ and $\mathrm{T} 70 \mathrm{H} / \mathrm{T} 70 \mathrm{H} \mathrm{B}_{1}$ sons with the $\mathrm{Y}$ chromosome of the random-bred Swiss mice. Of each of these 4 groups, 15 males were each caged with two females (one each week) and these were killed on Day 13 after finding a vaginal plug to count the number of implantations. Thereafter, the males (2-6 months old) were killed. The numbers of sperm heads in each caput epididymidis (Searle \& Beechey, 1974) were counted with a haemocytometer (16 squares per caput). The values for the right and left sides were summed and compared with those for the control mice (Table 5). The morphology of the spermatozoa in the epididymides was assessed by a modification of the descriptions given by Bruce, Furrer \& Wyrobek (1974). For each group, 7 males were used and 100 cells were scored per animal. As a measure of severe morphological abnormality, the frequencies of the sperm shapes E-H (see Bruce et al., 1974) were pooled (Table 5). Meiotic preparations made according to the method of Evans, Breckon \& Ford (1964) and stained with the BSG technique of Sumner (1972) were used for observations on late diplotene-metaphase 1 primary spermatocytes. The males were the same 7 as were used for the sperm morphology studies. Five of 
the sterile $\mathrm{T} 70 \mathrm{H} /+\mathrm{Y}^{*} \mathrm{~F}_{1}$ males and $2 M . m$. molossinus males were also analysed. Fifty (50) diplotene-metaphase 1 spermatocytes were scored per male to give estimates of the stage of first meiotic prophase-metaphase 1, as previously described (de Boer \& Groen, 1974). Class 1 is characterized by the most despiralized bivalents, Class 3 by the most contracted ones and Class 2 contains all stages in between. In animals heterozygous for the $\mathrm{T} 70 \mathrm{H}$ reciprocal translocation, chiasma formation in the multivalent was recorded and scored by reference to the notations RIV (ring of 4 chromosomes), CIV13, (chain of 4 with a chiasma lacking in the translocated segment of Chromosome 13), CIV $1_{i}$ (chain of 4 with a chiasma lacking in the interstitial segment of Chromosome 1) and CIII + I (a trivalent and univalent, no association in the segments $13_{\text {t }}$ and $1_{i}$ ). For graphical illustrations of the configurations, see Text-fig. 1. The frequency of cells with two chiasmata in the long translocated segment of Chromosome 1 was scored in the spiralization Classes 1 and 2 because of its potential as a measure of the chiasma-forming capacity of the cell (de Boer \& van der Hoeven, 1977). X and Y chromosomes were regarded as separate when the telomeric end of the $\mathrm{Y}$ was not in close proximity to the telomeric end of the $\mathrm{X}$. When the $\mathrm{X}$ and $\mathrm{Y}$ chromosomes were aligned, separation was assumed when the distance between the two telomeric ends exceeded the length of the $Y$ chromosome.

Two sterile $\mathrm{T} 70 \mathrm{H} /+\mathrm{Y}^{*} \mathrm{~F}_{1}$ males were killed for electron microscope observations on pachytene primary spermatocytes, using a modification (de Boer \& Branje, 1979) of the whole-mount spreading technique for mammalian cells described by Moses (1977). Nonparametric statistical methods were used to assess the significance of differences.

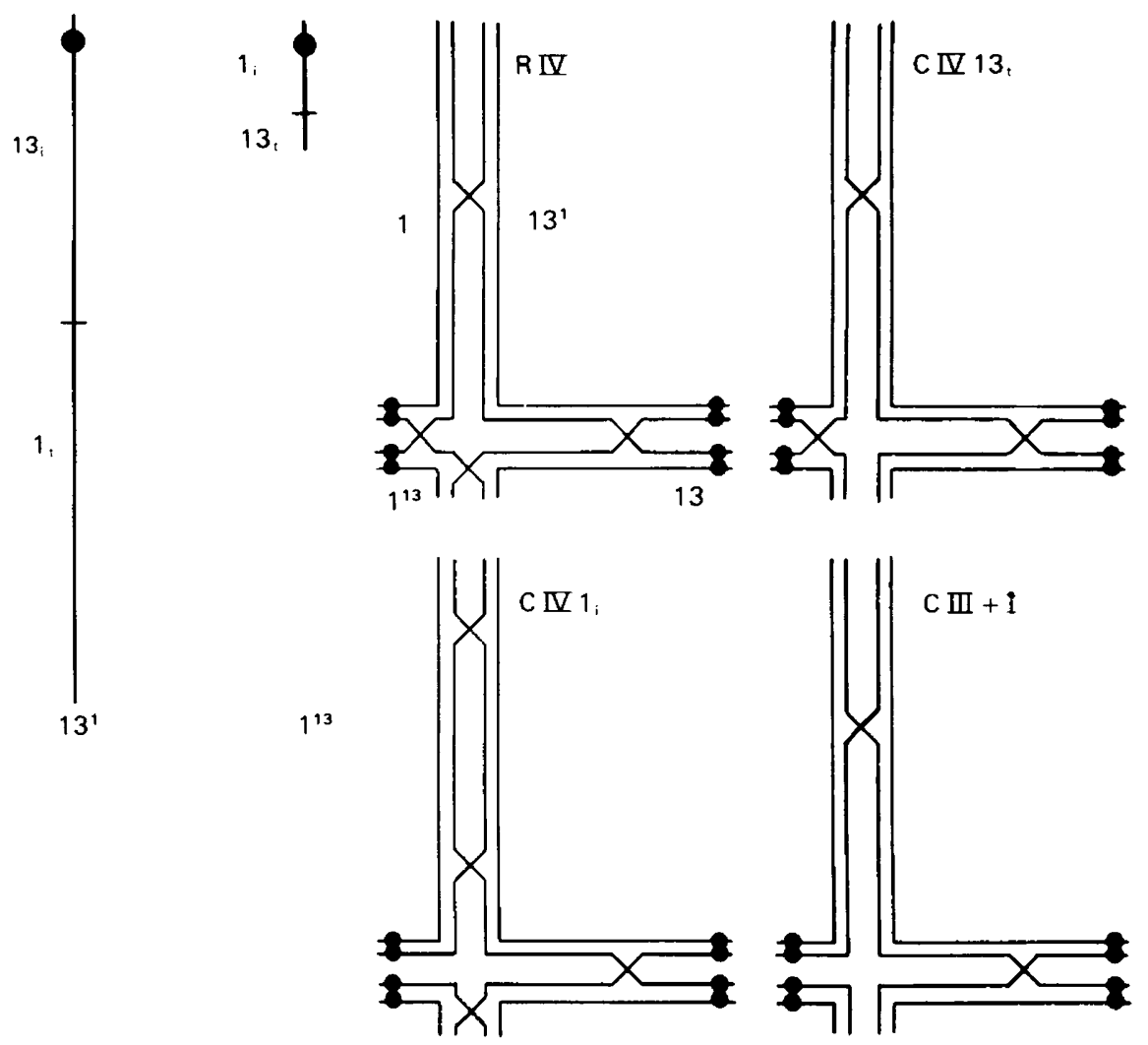

Text-fig. 1. Diagrams of the multivalent configurations encountered for the $T(1 ; 13) 70 \mathrm{H}$ reciprocal mouse translocation together with the notations of the chromosomes involved and

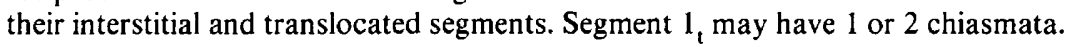




\section{Results}

\section{Light microscope observations}

Table 1 gives the frequencies of cells with dissociated sex chromosomes in the three spiralization classes. Values were lowest for $M . m$. molossinus with an overall dissociation frequency of $13.3 \%$. The other groups showed much higher fractions of univalent X,Y cells, especially in the cells with the most contracted bivalents. The observation of an obvious increase in $\mathrm{X}, \mathrm{Y}$ separation with the progression from late diplotene to metaphase 1 is in agreement with earlier work (de Boer, 1976). When the frequencies obtained from the 4 groups of males of the Swiss backcross were pooled in two ways, translocation heterozygotes against structural homozygotes and $\mathrm{Y}^{*}$-carrying animals against $\mathrm{Y}$-carrying animals, there was no difference for the first comparison but the $\mathrm{Y}^{*}$-carrying animals exhibited more dissociation $(P<0.05$, Mann-Whitney U test).

Table 1. The percentages of cells (no. in parentheses) with dissociated sex chromosomes in the three spiralization classes from late diplotene to metaphase I in mice of the various genotypes and karyotypes

\begin{tabular}{|c|c|c|c|c|}
\hline \multirow[b]{2}{*}{ Genotype } & \multirow{2}{*}{$\begin{array}{l}\text { No. of } \\
\text { males }\end{array}$} & \multicolumn{3}{|c|}{ Spiralization class } \\
\hline & & 1 & 2 & 3 \\
\hline $\mathrm{T} 70 \mathrm{H} /+\mathrm{Y}^{*} \mathrm{~F}_{1}$ & 5 & $53 \cdot 8(13)$ & $69 \cdot 2(91)$ & $87.7(145)$ \\
\hline $\mathrm{T} 70 \mathrm{H} /+\mathrm{Y}^{*} \mathrm{~B}_{1}$ & 7 & $36.8(38)$ & $67.0(112)$ & $89.0(200)$ \\
\hline $\mathrm{T} 70 \mathrm{H} /+\mathrm{Y} \mathrm{B}_{1}$ & 7 & $5 \cdot 9(34)$ & $20 \cdot 2(183)$ & $49 \cdot 2(124)$ \\
\hline$+/+Y^{*} B_{1}$ & 7 & $28 \cdot 6(35)$ & $41 \cdot 0(173)$ & $85.2(142)$ \\
\hline $\mathrm{T} 70 \mathrm{H} / \mathrm{T} 70 \mathrm{H} \mathrm{Y} \mathrm{B}$ & 7 & $9.8(41)$ & $32 \cdot 7(214)$ & $77.9(95)$ \\
\hline M. m. molossinus & 2 & $0 \quad$ (17) & $9 \cdot 2(65)$ & $34 \cdot 8(23)$ \\
\hline
\end{tabular}

Table 2 shows the percentages of the various types of $770 \mathrm{H} /+$ multivalent configurations. The three crosses with 'molossinus' did not differ significantly $\left(\chi_{4}^{2}=3.00,0.20<P<0.30\right)$. When a comparison with respect to the RIV $+\mathrm{CIV} / \mathrm{CIII}+\mathrm{I}$ ratio within spiralization Class 2 cells was made between the 19 males of these three genotypes and 7 random-bred Swiss males (de Boer, 1976), a significant difference emerged $(P<0.001$, Mann-Whitney $U$ test $)$ with the hybrids having fewer cells with $\mathrm{CIII}+\mathrm{I}$ configurations. The same comparison was made with respect to the chiasma frequency of segment $1_{t}$, using the 30 random-bred Swiss T70H/+males studied by de Boer \& van der Hoeven (1977) as controls (see Table 3). The M. musculus $\times M$. m. molossinus hybrids showed the higher chiasma frequencies $(P<0.001$, Mann-Whitney $\mathrm{U}$ test). Both the lower share of CIII + I configuration and the increase in the chiasma frequency for segment $1_{t}$ within the multivalent configuration in the 'molossinus' hybrids point in the direction of more meiotic recombination taking place in the hybrids.

Table 2. The percentage distribution of $\mathrm{T} 70 \mathrm{H}$ multivalent configurations in the various $M$. musculus $\times M$. m. molossinus hybrids

\begin{tabular}{lcccc}
\hline & & \multicolumn{3}{c}{ Multivalent configuration } \\
\cline { 3 - 5 } \multicolumn{1}{c}{ Genotype } & $\begin{array}{c}\text { Total no. } \\
\text { of cells }\end{array}$ & RIV + CIV 13, & CIV 1 $_{\mathrm{i}}$ & $\mathrm{CIII}+\mathrm{I}$ \\
\hline $\mathrm{T} 70 \mathrm{H} /+\mathrm{Y}^{*} \mathrm{~F}_{1}$ & 237 & $2 \cdot 1$ & $76 \cdot 8$ & $21 \cdot 1$ \\
$\mathrm{~T} 70 \mathrm{H} /+\mathrm{Y}^{*} \mathrm{~B}_{1}$ & 321 & $2 \cdot 8$ & $73 \cdot 8$ & $23 \cdot 4$ \\
$\mathrm{~T} 70 \mathrm{H} /+\mathrm{Y} \mathrm{B}_{1}$ & 340 & $2 \cdot 1$ & $79 \cdot 4$ & $18 \cdot 5$ \\
$\mathrm{~T} 70 \mathrm{H} /+$ Swiss $\dagger$ & 1442 & $3 \cdot 7$ & $62 \cdot 3$ & $34 \cdot 0$ \\
\hline
\end{tabular}

$\dagger$ Data from de Boer (1976). 
Table 3. Chiasma frequencies in segment $1_{t}$ of the $\mathrm{T} 70 \mathrm{H}$ translocation multivalent in cells (no. in parentheses) of the spiralization Classes 1 and 2

\begin{tabular}{lll}
\hline & \multicolumn{2}{c}{ Chiasma frequency $1_{\mathrm{t}}$} \\
\cline { 2 - 3 } \multicolumn{1}{c}{ Genotype } & \multicolumn{1}{c}{ Class 1 } & \multicolumn{1}{c}{ Class 2 } \\
\hline $\mathrm{T} 70 \mathrm{H} /+\mathrm{Y}^{*} \mathrm{~F}_{1}$ & $1.82(11)$ & $1.58(88)$ \\
$\mathrm{T} 70 \mathrm{H} /+\mathrm{Y}^{*} \mathrm{~B}_{1}$ & $1.44(25)$ & $1.41(106)$ \\
$\mathrm{T} 70 \mathrm{H} /+\mathrm{Y} \mathrm{B}_{1}$ & $1.85(34)$ & $1.40(184)$ \\
$\mathrm{T} 70 \mathrm{H} /+$ Swiss $\dagger$ & $1.38(549)$ & $1.27(2446)$ \\
\hline
\end{tabular}

† Data from de Boer \& van der Hoeven (1977).

When the spiralization class distribution of primary spermatocytes from the $\mathrm{T} 70 \mathrm{H} /+M . m$. molossinus hybrids was compared with that of $\mathrm{T} 70 \mathrm{H} /+$ Swiss males (Table 4), more cells were classified as contracted (Class 3$)$ in the hybrids $\left(\chi_{2}^{2}=115.8, P<0.001\right)$.

Table 4. The percentage distribution of late diplotenemetaphase I primary spermatocytes in the three classes of spiralization

\begin{tabular}{|c|c|c|c|c|}
\hline \multirow[b]{2}{*}{ Genotype } & \multirow{2}{*}{$\begin{array}{l}\text { Total no. } \\
\text { of cells }\end{array}$} & \multicolumn{3}{|c|}{ Spiralization class } \\
\hline & & 1 & 2 & 3 \\
\hline $\left.\begin{array}{l}\mathrm{T} 70 \mathrm{H} /+\mathrm{Y}^{*} \mathrm{~F}_{1} \\
\mathrm{~T} 70 \mathrm{H} /+\mathrm{Y}^{*} \mathrm{~B}_{1} \\
\mathrm{~T} 70 \mathrm{H} /+\mathrm{Y} \mathrm{B}_{1}\end{array}\right\}$ & 904 & $10 \cdot 6$ & 41.8 & $50 \cdot 5$ \\
\hline
\end{tabular}

$\dagger$ Data from de Boer (1976).

\section{Electron microscopic observations during pachytene}

Inspection of the $\mathrm{X}$ and $\mathrm{Y}$ chromosome axial elements in 114 sex vesicles from two T70H/+ $\mathrm{Y}^{*} \mathrm{~F}_{1}$ males and in 110 sex vesicles from the control $\mathrm{Rb} 4 \mathrm{Bnr} /+$ and $\mathrm{Rb} 163 \mathrm{H} /+$ males showed that there were 63.2 and $94.5 \%$ sex vesicles with telomeric $X, Y$ contact in the experimental and control animals respectively. When in the $T 70 \mathrm{H} /+\mathrm{Y}^{*} \mathrm{~F}_{1}$ animals, $\mathrm{X}, \mathrm{Y}$ contact failed, the telomeric segment of the $X$ was often found (28.9\%) paired with the centromeric segment of the $\mathrm{X}$ (Pl. 1, Figs 1 and 2). The extent of X,Y contact was tentatively assessed as the fraction of the length of the $Y$ chromosome which paired with the $X$ chromosome. For $T 70 H /+F_{1}$ sex vesicles with $\mathrm{X}, \mathrm{Y}$ contact, this was $6 \cdot 6 \%(n=26)$ and for sex vesicles from $\mathrm{Rb} /+$ males, this was $11.5 \%$ $(n=100)$. The $\mathrm{Y}$ chromosome was maximally paired for 30 and $75 \%$ of its length in the hybrids and the Robertsonian translocation ( $\mathrm{Rb}$ )-carrying males, respectively. The results for frequency and extent of pairing therefore lead to the conclusion that pachytene sex chromosome pairing is reduced in $\mathrm{T} 70 \mathrm{H} /+\mathrm{Y}^{*} \mathrm{~F}_{1}$ males. During these observations, the impression was gained that the $\mathrm{T} 70 \mathrm{H}$ multivalent could be in close association with the axial elements of the sex chromosomes, although this association was not of a constant nature.

\section{Sperm production and morphology}

The difference in sperm count (Table 5) between $B_{1}$ translocation heterozygotes with a $Y$ and those with a $\mathrm{Y}^{*}$ chromosome was not significant $(P<0.06$, Mann-Whitney $\mathrm{U}$ test). The comparison for all males with a $\mathrm{Y}$ and all those with a $\mathrm{Y}^{*}$ chromosome was also not significant $(P=0.23)$, but structurally homozygous males had a higher sperm count than did those that were structurally heterozygous $\left(B_{1}\right.$ generation, $\left.P=0.03\right)$. 
Male mice heterozygous or homozygous with a $\mathrm{Y}^{*}$ chromosome had fewer abnormal $\mathrm{Y}^{*}$ spermatozoa (Table 5) than did the $\mathrm{Y}$-carrying males $\left(\mathrm{B}_{1}\right.$ generation, $\left.P<0.025\right)$. Irrespective of the source of the $\mathrm{Y}, \mathrm{T} 70 \mathrm{H}$-carrying males produced more aberrant spermatozoa than did structurally homozygous males $\left(\mathrm{B}_{1}\right.$ generation, $P<0.01$ ).

Table 5. Sperm counts, sperm morphology (\% of severely affected spermatozoa) and the total number of implantations in mice of different genotypes

\begin{tabular}{lccc}
\hline \multicolumn{1}{c}{ Genotype } & Sperm count & Sperm morphology & $\begin{array}{c}\text { No. of } \\
\text { implantations }\end{array}$ \\
\hline $\mathrm{T} 70 \mathrm{H} /+\mathrm{Y}^{*} \mathrm{~F}_{1}$ & $31 \cdot 2 \pm 34 \cdot 0(10)$ & $12 \cdot 0(2)$ & $0(18)$ \\
$\mathrm{T} 70 \mathrm{H} /+\mathrm{Y}^{*} \mathrm{~B}_{1}$ & $35 \cdot 9 \pm 65 \cdot 5(14)$ & $22 \cdot 6 \pm 23 \cdot 8(6)$ & $2 \cdot 6 \pm 4 \cdot 7(30)$ \\
$\mathrm{T} 70 \mathrm{H} /+\mathrm{Y} \mathrm{B}_{1}$ & $93.4 \pm 143 \cdot 0(34)$ & $37 \cdot 7 \pm 22 \cdot 6(7)$ & $3 \cdot 2 \pm 6 \cdot 4(41)$ \\
$+/+\mathrm{Y}^{*} \mathrm{~B}_{1}$ & $211.4 \pm 189 \cdot 1(21)$ & $2 \cdot 9 \pm 3 \cdot 8(7)$ & $8 \cdot 6 \pm 8 \cdot 1(30)$ \\
$\mathrm{T} 70 \mathrm{H} / \mathrm{T} 70 \mathrm{H} \mathrm{B}_{1}$ & $235 \cdot 5 \pm 226 \cdot 1(22)$ & $14.9 \pm 15 \cdot 2(7)$ & $8 \cdot 2 \pm 7 \cdot 9(40)$ \\
Random-bred Swiss & $417 \pm 71$ & $7.9 \pm 4 \cdot 7(10) \dagger$ & \\
\hline
\end{tabular}

Values are mean \pm s.d. for the no. of males or females given in parentheses.

$\uparrow$ Includes the less severely affected shapes as well (see Bruce et al., 1974).

When Spearman rank correlations were computed for the epididymal sperm count and various other values, the correlation coefficient was significant $(P<0.001)$ for the mean number of implantation sites $\left(r_{\mathrm{s}}=0.81\right)$, percentage $\mathrm{X}, \mathrm{Y}$ dissociation $\left(r_{\mathrm{s}}=-0.81\right)$, and the fraction of primary spermatocytes with 'contracted' short bivalents (Class 3$)\left(r_{s}=-0.81\right)$. When the data were partitioned, the correlation between the sperm count and $\mathrm{X}, \mathrm{Y}$ univalence was higher for $\mathrm{Y}^{*}$ than for $\mathrm{Y}$ chromosome-carrying males $(-0.88$ and -0.66$)$ respectively. Comparison of $\mathrm{T} 70 \mathrm{H} /+$ males with $+/+$ and $\mathrm{T} 70 \mathrm{H} / \mathrm{T} 70 \mathrm{H}$ males gave similar $(-0.87$ and -0.86$)$ correlation values. There was no apparent correlation between the sperm count and the proportion of spermatozoa with severely abnormal heads $\left(r_{s}=-0 \cdot 15\right)$.

\section{Observations on secondary spermatocytes}

From two males of the $+/+Y^{*} B_{1}$ karyotype with sperm counts of 69 and 41, 50 primary and 50 secondary spermatocytes were scored for $\mathrm{X}, \mathrm{Y}$ dissociation and sex chromosome aneuploidy. Recognition of the sex chromosomes in secondary spermatocytes was based on the description of Beechey (1973). The two males had $X, Y$ univalence frequencies of 84 and $78 \%$ respectively, whereas in a total of 102 secondary spermatocytes, no hyperhaploid and two hypohaploid cells with 19 chromosomes (including a sex chromosome) were found. These two cells may have resulted from chromosome loss during preparation. From a series of four other $+/+Y^{*} B_{1}$ male mice with an average sperm count of 407.3 a total number of 261 metaphase II cells was scored; 2 contained 21 chromosomes, both with a single Y-chromosome, and 5 contained 19 chromosomes including a sex chromosome. There was therefore no detectable X,Y univalence leading to sex chromosome aneuploidy among secondary spermatocytes.

\section{Discussion}

During the pachytene stages of meiosis in male mammals including man, a certain length of the $\mathrm{Y}$ chromosome is paired with the $\mathrm{X}$ chromosome (for review, Solari, 1974). This portion may be constant for the whole of the pairing stage or it may decrease after early pachytene as in $M u s$ musculus (Tres, 1977). The association, as demonstrated by the use of the staining characteristics of BrdU-differentiated chromatids to show exchange, can lead to crossing-over and a chiasma in the Armenian hamster (Allen, 1979), but most probably does not in the mouse 
PLATE 1
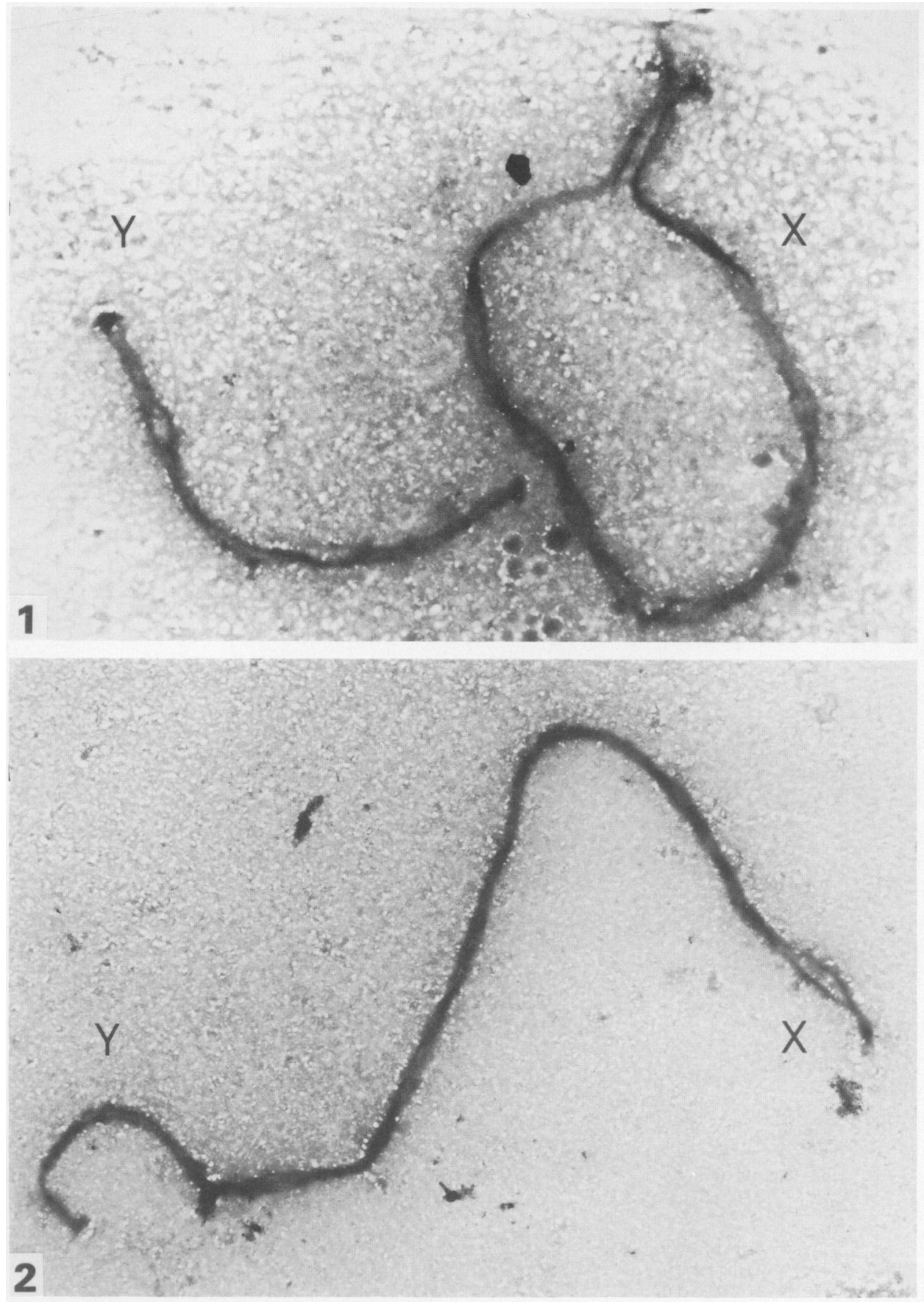

Fig. 1. Electron micrograph of the axial elements of the sex chromosomes of a $\mathrm{T} 70 \mathrm{H} /+\mathrm{Y}^{*} \mathrm{~F}_{1}$ male mouse. The $\mathrm{X}$ chromosome folds back on itself, leaving the $\mathrm{Y}$ unpaired.

Fig. 2. A sex vesicle with $X, Y$ telomeric contact from a male $T 70 H /+Y^{*} F$, mouse.

(Facing p. 241) 
(Allen \& Latt, 1976). Thus, despite the higher chiasma frequencies found in the $M$. musculus $\times$ $M$. m. molossinus hybrids compared with the random-bred Swiss stock (when the frequency for the segments $1_{t}$ and $13_{t}$ of the T $70 \mathrm{H}$ translocation is taken as indicative of the 'overall' chiasma frequency; de Boer \& van der Hoeven, 1977), they are not accompanied by normal sex chromosome pairing. A similar observation was made by Rapp, Therman \& Denniston (1977) for C57BL $q \times$ DBA2 $\sigma F_{1}$ mice, but contradictory results have been reported by Purnell (1973) who found high sex chromosome univalent frequencies paralleling low chiasma counts in fertile SF/CAM mice. Hultén, Solari \& Skakkebaek (1974) also describe a human male in which defective meiotic pairing of autosomal material was paralleled by the inability of the sex chromosomes to condense into a sex vesicle and to form a synaptonemal complex. Thus, for mammals with an achiasmate sex bivalent and taking into account that autosomal meiotic pairing constitutes a prerequisite for crossing-over to occur, autosome and sex chromosome pairing must be processes determined by partly overlapping sets of genes.

The present electron microscope observations demonstrate two factors which contribute to the frequency of X,Y univalence seen in late diplotene-metaphase 1. (1) Since pachytene spermatocytes chosen for observation represent all pachytene stages, the frequency of cells with detached sex chromosomes within or without a sex vesicle seems sufficiently high in the sterile $\mathrm{T} 70 \mathrm{H} /+\mathrm{Y}^{*} \mathrm{~F}_{1}$ males to suggest that in some of the cells, there is complete asynapsis between the $\mathrm{X}$ and $\mathrm{Y}$ chromosome. (2) When contact is established, the length of the $\mathrm{X}$ chromosome paired with the $Y$ chromosome is less with respect to the maximal and the average value than the control values.

Considering the animals from the $\mathrm{B}_{1}$ generation only, high correlations were found between the sperm count and both the frequency of 'Class 3' spermatocytes with contracted bivalents and the frequency of late diplotene-metaphase 1 cells with univalent sex chromosomes. Our explanation of the first correlation is that when a late diplotene-diakinesis spermatocyte degenerates, a 'late' nucleus image is produced in which the chromosomes usually have fuzzy borders. As part of the process of degeneration, the already deficient association of the sex chromosomes dissolves even further and a marked increase of univalent sex chromosomes is produced in the spiralization Classes 2 and 3 (see Table 1). Furthermore, we assume the pachytene sex chromosome behaviour of the $B_{1}$ generation to be similar to the electron microscope sex chromosome observations from the sterile $F_{1}$ males, especially when a $Y^{*}$ chromosome is present. Thus, the high correlation between the sperm count and the frequency of primary spermatocytes with $\mathrm{X}, \mathrm{Y}$ univalents has two contributory factors: the first is the absence of or insufficient pairing during the pachytene stages, and the second is precocious dissolution of the fragile bond between the sex chromosomes in degenerating diplotene-metaphase I spermatocytes.

The material from the $B_{1}$ generation suggests that two factors seem to influence the efficiency of $\mathrm{X}, \mathrm{Y}$ pairing in the hybrids. (1) Mice with a $\mathrm{Y}^{*}$ chromosome have a higher $\mathrm{X}, \mathrm{Y}$ univalent frequency than do those with a $Y$ chromosome, although no difference in sperm count was observed. (2) All four $B_{1}$ genotypes were characterized by very marked heterogeneity as expressed by the relatively large standard deviations for the sperm counts in all groups (see Table 5). The probable basis for this must be the segregation of cross-over and non-cross-over chromatids from $M$. musculus and $M . m$. molossinus origins in the $\mathrm{F}_{1}$ parent used to produce this generation. This phenomenon was particularly marked in mice with the $\mathrm{T} 70 \mathrm{H} /+\mathrm{Y}$ and $\mathrm{T} 70 \mathrm{H} / \mathrm{T} 70 \mathrm{H} \mathrm{Y} \mathrm{B}_{1}$ karyotypes. Autosomal genes may, therefore, also play a role in the efficiency of $\mathrm{X}, \mathrm{Y}$ pairing.

Familial occurrence of fractional or complete $X, Y$ separation at late diplotene-metaphase 1 in the mouse has been described by Beechey (1973) and Sotomayor \& Cumming (1977). Like Beechey (1973), we did not find any sign of sex chromosome aneuploidy in secondary spermatocytes of mice with high frequencies of $X, Y$ separation, These results, together with our finding of a very high correlation between the sperm count and the fraction of separated $X, Y$ 
chromosomes, suggest that primary spermatocytes with absence or sufficient reduction of $\mathrm{X}, \mathrm{Y}$ pairing can be cell lethals (see Beechey, 1973; Miklos, 1974).

Other genetic conditions in the mouse (excluding $X$ autosome translocations) associated with an increased level of X,Y univalence are the $S x r$ factor (Winsor, Ferguson-Smith \& Shire, 1978), the XYY chromosome constitution (Evans, Beechey \& Burtenshaw, 1978) and tetraploid spermatocytes (Solari \& Moses, 1977). Although fertility is retained, Sxr mice generally have lower and more variable testicular weights (Cattanach, 1975). Pairing competition within the sex vesicle can be considered to result in deficient sex chromosome pairing of mice with an XYY karyotype, thus leading to the azoö- or oligospermic condition observed in these animals, but the results of Evans et al. (1978) also suggest that an effect of the second $\mathrm{Y}$ chromosome on spermatogonial development contributes to the low sperm production. In subfertile men, Chandley, Maclean, Edmond, Fletcher \& Watson (1976) observed a negative correlation between the fraction of diakinesis-metaphase 1 cells with $X, Y$ univalents and the number of secondary spermatocytes in the same preparation. Taking all the evidence together, the relation between abnormal X,Y pairing or lack of pairing and spermatocyte death seems to be firmly established in the mouse, a conclusion which can probably be extended to man.

Routine histology on the testes of $8 \mathrm{~T} 70 \mathrm{H} /+\mathrm{Y}^{*} \mathrm{~F}_{1}$ sterile male hybrids did not reveal any abnormality in the spermatogonial compartment. In two males, the primary spermatocytes had started to degenerate during mid-pachytene. In the others, degeneration was most extensive in stage 12 of the cycle of the seminiferous epithelium (diakinesis-metaphase 1) which conforms with the morphological characteristics of these cells as observed in air-dried preparations.

The presence of the $\mathrm{T} 70 \mathrm{H} /+$ reciprocal translocation did not influence the dissociation behaviour of the sex chromosomes, although on average much lower sperm counts were found. In previous comparisons (de Boer, 1976), $\mathrm{T} 70 \mathrm{H} /+$ mice on a random-bred Swiss background produced $\approx 80 \%$ of the spermatozoa of $+/+$ males, but the present results gave a much greater reduction. An identical phenomenon is described by Forejt (1976) for the T(14;15)6Ca mouse translocation.

In $\mathrm{T} 70 \mathrm{H} /+$ random-bred Swiss male mice, no increase in the percentage of spermatozoa with abnormally shaped heads was observed (de Boer, 1976). However, an effect of this translocation on sperm morphology in the $B_{1}$ generation was obtained, the comparison between genetic backgrounds for $\mathrm{T} 70 \mathrm{H} /+$ yielding an inverse relation between the sperm count and the percentage of abnormal spermatozoa whereas the comparison within genetic background $\left(B_{1}\right.$ generation) did not. A finding similar to that of Krzanowska (1976) was of an influence of the source of the $\mathrm{Y}$ chromosome on sperm morphology; males with the $\mathrm{Y}^{*}$ chromosome produced more normal spermatozoa. Morphologically deviant spermatozoa are of interest because of their rapid increase in number after the treatment of mice with $\mathrm{X}$-rays and chemical mutagens (Bruce et al., 1974; Wyrobek \& Bruce, 1975). In agreement with existing knowledge (see Wyrobek, Heddle \& Bruce, 1975), this study shows that genetic factors, both autosomal and Y chromosomal, play a role. The results also suggest that spermatid density during spermiogenesis is unlikely to be an important factor for normal sperm morphology.

We thank Riëtte van Beek, Piet Sterrenburg, Piet van Kleef, Frits van der Hoeven and Sjouke Zwanenburg for technical assistance; Mr Colin Beechey for help with the manuscript; and Professor Alfred Gropp for the generous gift of the $M$. m. molossinus males.

\section{References}

Allen, J.W. (1979) BrdU-dye characterization of late replication and meiotic recombination in Armenian hamster germ cells. Chromosoma 74, 189-207.

Allen, J.W. \& Latt, S.A. (1976) In vivo BrdU-33258
Hoechst analysis of DNA replication kinetics and sister chromatid exchange formation in mouse somatic and meiotic cells. Chromosoma 58, 325340 . 
Beechey, C.V. (1973) X-Y chromosome dissociation and sterility in the mouse. Cytogenet. Cell Genet. 12, $60-67$

Bruce, W.R., Furrer, R., Goldberg, R.B. \& Meistrich, M.L. (1973) Genetic control of the kinetics of mouse spermatogenesis. Genet. Res. 22, 155-167.

Bruce, W.R., Furrer, R. \& Wyrobek, A.J. (1974) Abnormalities in the shape of murine sperm after acute testicular X-irradiation. Mutation Res. 23, 381-386.

Cattanach, B.M. (1975) Sex reversal in the mouse and other mammals. In The Early Development of Mammals, pp. 305-317. Eds M. Balls \& A. E. Wild. Cambridge University Press.

Chandley, A.C., Maclean, N., Edmond, P., Fletcher, J. \& Watson, G.S. (1976) Cytogenetics and infertility in man. 2. Testicular histology and meiosis. Annls Hum. Genet. 40, 165-176.

de Boer, P. (1976) Male meiotic behaviour and male and female litter size in mice with the $\mathrm{T}(2 ; 8) 26 \mathrm{H}$ and $\mathrm{T}(1 ; 13) 70 \mathrm{H}$ reciprocal translocations. Genet. Res. 27, 369-387.

de Boer, P. \& Branje, H.E.B. (1979) Association of the extra chromosome of tertiary trisomic male mice with the sex chromosomes during first meiotic prophase, and its significance for impairment of spermatogenesis. Chromosoma 73, 369-379.

de Boer, P. \& Groen, A. (1974) Fertility and meiotic behaviour of male $\mathrm{T} 70 \mathrm{H}$ tertiary trisomics of the mouse (Mus musculus). A case of preferential telomeric meiotic pairing in a mammal. Cytogenet. Cell Genet. 13, 489-510.

de Boer, P. \& van der Hoeven, F.A. (1977) Son-sire regression based heritability estimates of chiasma frequency, using $\mathrm{T} 70 \mathrm{H}$ mouse translocation heterozygotes, and the relation between univalence, chiasma frequency and sperm production. Heredity 39, 335-343.

Dev, V.G., Miller, D.A., Tantravahi, R., Schreck, R.R., Roderick, T.H., Erlanger, B.F. \& Miller, O.J. (1975) Chromosome markers in Mus musculus: differences in C-banding between the subspecies $M$. m. musculus and $M$. m. molossinus. Chromosoma 53, 335-344.

Evans, E.P., Breckon, C. \& Ford, C.E. (1964) An air-drying method for meiotic preparations from mammalian testes. Cytogenetics 3, 289-294.

Evans, E.P., Beechey, C.V. \& Burtenshaw, M.D. (1978) Meiosis and fertility in XYY mice. Cytogenet. Cell Genet. 20, 249-263.

Forejt, J. (1976) Spermatogenic failure of translocation heterozygotes affected by $\mathrm{H}-2$ linked gene in mouse. Nature, Lond. 260, 143-145.

Gray, A.P. (1953) Mammalian Hybrids. Commonwealth Agric. Bureau, Farnham Royal, Bucks, England.

Hultén, M., Solari, A.J. \& Skakkebaek, N.E. (1974)
Abnormal synaptonemal complex in an oligochiasmatic man with spermatogenic arrest. Hereditas 78, 105-116.

Krzanowska, H. (1976) Inheritance of sperm head abnormality types in mice-the role of the $\mathrm{Y}$ chromosome. Genet. Res. 28, 189-198.

Miklos, G.L.G. (1974) Sex-chromosome pairing and male fertility. Cytogenet. Cell Genet. 13, 558-577.

Moses, M.J. (1977) Synaptonemal complex karyotyping in spermatocytes of the Chinese hamster (Cricetulus griseus). 1. Morphology of the autosomal complement in spread preparations. Chromosoma 60, 99-125.

Nijhoff, J.H., van Beek, R. \& de Boer, P. (1977) Translocation induced male sterility. Mouse News Letter 57, 39-40.

Purnell, DJ. (1973) Spontaneous univalence at male meiosis in the mouse. Cytogenet. Cell Genet. 12, 327-335.

Rapp, M., Therman, E. \& Denniston, C. (1977) Non pairing of the $\mathrm{X}$ and $\mathrm{Y}$ chromosomes in the spermatocytes of $\mathrm{BD} \mathrm{F}_{1}$ mice. Cytogenet. Cell Genet. 19, 85-93.

Searle, A.G. \& Beechey, C.V. (1974) Sperm-count, egg-fertilization and dominant lethality after $X$ irradiation of mice. Mutation Res. 22, 63-72.

Searle, A.G., Ford, C.E. \& Beechey, C.V. (1971) Meiotic disjunction in mouse translocations and the determination of centromere position. Genet. Res. 27, 369-387.

Solari, A.J. (1974) The behaviour of the XY pair in mammals. Int. Rev. Cytol. 28, 217-236.

Solari, A.J. \& Moses, M.J. (1977) Synaptonemal complex in a tetraploid mouse spermatocyte. Expl Cell Res. 108, 464-467.

Sotomayor, R.E. \& Cumming, R.B. (1977) XY dissociation in mice: a model that may account for sex aneuploidy in humans. Genetics, Princeton 86, 60-61.

Sumner, A.T. (1972) A simple technique for demonstrating centromeric heterochromatin. Expl Cell Res. 75, 304-306.

Tres, L.L. (1977) Extensive pairing of the XY bivalent in mouse spermatocytes as visualized by whole-mount electron microscopy. J. Cell Sci. 25, 1-15.

Winsor, E.J.T., Ferguson-Smith, M.A. \& Shire, J.G.M. (1978) Meiotic studies in mice carrying the sex reversal (Sxr) factor. Cytogenet. Cell Genet. 21, 11-18.

Wyrobek, A.J. \& Bruce, W.R. (1975) Chemical induction of sperm abnormalities in mice. Proc. natn. Acad. Sci. U.S.A. 72, 4425-4429.

Wyrobek, A.J., Heddle, J.A. \& Bruce, W.R. (1975) Chromosomal abnormalities and the morphology of mouse sperm heads. Can. J. Genet. Cytol. 17, $675-681$. 